\title{
Wheat germ agglutinin binding proteins in the cellular slime moulds Dictyostelium and Polysphondylium
}

\author{
YuZURU Kubohara* and KoJI OKamoto \\ Department of Botany, Faculty of Science, Kyoto University, Sakyo-ku, Kyoto, Kyoto 606, Japan
}

(Received 29 October 1990; revised 14 February 1991; accepted 27 February 1991)

\begin{abstract}
Analysis of the wheat germ agglutinin (WGA) binding proteins in the cellular slime moulds Dictyostelium mucoroides, $D$. rosarium, $D$. purpureum, Polysphondylium violaceum and $P$. pallidum revealed many cell-type specific proteins in each species examined. Furthermore, three species $D$. mucoroides, $D$. rosarium and $P$. violaceum, were found to have a wst34-like protein in their stalk cells. Wst34, which was originally identified in D. discoideum, is a stalk-specific WGA-binding protein having a molecular mass of $34 \mathrm{kDa}$ and pI values of between $5 \cdot 5$ and $6 \cdot 5$.
\end{abstract}

\section{Introduction}

The development of the cellular slime mould Dictyostelium discoideum through cell differentiation into the advanced stage is regulated by the activation or inactivation of many genes and the appearance or disappearance of many proteins. The cells acquire some of their individual characteristics by post-translational modification of these proteins. Analysis of the developmental changes by determination in 1-D gels of the total protein of $D$. discoideum, detected by Coomassie brilliant blue staining or biotin blotting, revealed so many proteins that it was difficult to identify the changes. However, developmental changes can also be determined by glycoprotein analysis using lectins.

Wheat germ agglutinin (WGA) is one of the most useful lectins for analysis of the development and differentiation of $D$. discoideum (Burridge \& Jordan, 1979; West \& McMahon, 1979; Kumagai et al., 1987; Oyama et al., 1988; Kubohara \& Okamoto, 1990). In this study, we extended our work on WGA-binding proteins to other species of cellular slime moulds, namely $D$. mucoroides, D. rosarium, D. purpureum, Polysphondylium violaceum and $P$. pallidum, and identified a number of cell-type specific proteins. Furthermore, in the course of these experiments we found 34-36 kDa WGA-binding proteins present specifically in stalk cells of $D$. mucoroides, $D$. rosarium and $P$. violaceum, which appeared to be similar to wst34, a WGA-binding protein present in the stalk cells of $D$. discoideum (Kubohara \& Okamoto, 1990). We examined whether these

Abbreviations: PAP, peroxidase conjugated anti-peroxidase; WGA, wheat germ agglutinin; 1- and 2-D, one- and two-dimensional. proteins were identical to wst34 by 2-D gel electrophoresis and by immunoblotting using two antisera which recognize wst 34 . We present here some of the characteristics of these proteins.

\section{Methods}

Strains, growth, development and cell-type separation. Dictyostelium discoideum (NC4), D. mucoroides (Dml1), D. rosarium (from Dr K. Inouye, Kyoto, originally used by $\mathrm{Dr} \mathrm{D}$. Waddell), $D$. purpureum (HDp8), Polysphondylium violaceum (Pv6) and P. pallidum (WS320) were used in this study. Dictyostelium cells were grown with Escherichia coli $\mathrm{B} / \mathrm{r}$ on SM agar plates (Sussman, 1951). Polysphondylium cells were grown with the same bacteria on 5-LP agar plates ( $0.5 \%$ lactose, $0.5 \%$ peptone; Ishida, 1980). All were allowed to develop at $21{ }^{\circ} \mathrm{C}$ in the light. Spores and stalk cells of each species were separated by passing the fruiting bodies through a $32 \mu \mathrm{m}$ filter. Proteins were solubilized with an appropriate amount of SDS sample buffer $(80 \mathrm{~mm}-\mathrm{Tris} / \mathrm{HCl}$, pH $6.8 ; 20 \%$ (w/v) glycerol ; 0.1 M-DTT; $2 \%$ (w/v) SDS; 1 mM-PMSF; $0.5 \mathrm{~mm}-\mathrm{N}$-tosyl-L-lysine chloromethyl ketone; $5 \mathrm{~mm}$-benzamidine) and insoluble materials were removed by centrifugation $(10000 \mathrm{~g}, 20 \mathrm{~min})$. The samples were used for 1-D or 2-D gel electrophoresis.

Preparation of antisera. Anti-wst34 serum was prepared as follows. Wst 34 which had been purified from $D$. discoideum stalk proteins using preparative SDS-PAGE and a WGA affinity column (Kubohara \& Okamoto, 1990) was used for immunization. Fifty microlitres of a solution of wst 34 in SDS sample buffer $\left(1 \mathrm{mg}\right.$ protein $\left.\mathrm{ml}^{-1}\right)$ was injected subcutaneously into a mouse (Balb/c female) with PBS $(20 \mathrm{~mm}$ phosphate buffer, $\mathrm{pH} 7.0 ; 0.9 \% \mathrm{NaCl}$ ) and Freund's complete adjuvant. Booster injections, using $20-50 \mu 1$ of the purified wst 34 with Freund's incomplete adjuvant, were given at 7-10 d intervals for one month. Anti-wst 34 serum was then prepared and stored at $4{ }^{\circ} \mathrm{C}$ with addition of the same amount of PBS and 0.01 vol. $1 \mathrm{M}-\mathrm{NaN}_{3}$. The antiserum raised against $D$. mucoroides stalk (anti-Dmst) which had been prepared in our previous work (Kubohara \& Okamoto, 1990) was used in this study. 
Gel electrophoresis and protein assay. SDS-PAGE was carried out using 10 or $12.5 \%$ acrylamide gels according to the method of Laemmli (1970) except that DTT $(0.1 \mathrm{M})$ was used instead of 2-mercaptoethanol. 2-D gel analysis was performed according to the method of O'Farrell (1975) as described previously (Kubohara \& Okamoto, 1990) except that isoelectric focussing was performed at $200 \mathrm{~V}$ for $16 \mathrm{~h}$ with subsequent focussing at $400 \mathrm{~V}$ for $1 \mathrm{~h}$. The protein assay was performed by a bicinchoninic acid method (Smith et al., 1985).

Detection of proteins. Proteins in 1-D or 2-D gels were transferred onto nitrocellulose membranes (Schleicher $\&$ Schuell) as described by Towbin et al. (1979). WGA-binding proteins were detected by the WGA-PAP method as described by Kumagai et al. (1987).

Immunoblots with anti-Dmst serum were carried out as described previously (Kubohara \& Okamoto, 1990). Immunoblots with antiwst34 serum were done as follows. Nitrocellulose membranes were incubated for $1 \mathrm{~h}$ with each of the following: (i) anti-wst 34 serum solution (obtained in this study, $1: 1000$ dilution), (ii) rabbit anti-mouse IgG (Cappel) solution ( $1: 500$ dilution), (iii) goat anti-rabbit IgG (Cappel) solution (1:100 dilution), (iv) PAP (Bio-Makor) solution (1:200 dilution). All solutions were made in PTS buffer $(10 \mathrm{~mm}-$ phosphate buffer, $\mathrm{pH} 7.0 ; 0.05 \%$ Tween $20 ; 0.9 \% \mathrm{NaCl} ; 0.025 \%$ $\mathrm{NaN}_{3}$ ). In steps (i) and (ii), non-fat milk [final concentration, $3 \%(\mathrm{w} / \mathrm{v})$ ] was added to reduce any non-specific reaction. Between each step, the membranes were washed three times in PTS for 5 min per wash. Colour

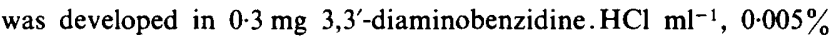
$\mathrm{H}_{2} \mathrm{O}_{2}$ in PTS.

\section{Results}

WGA-binding proteins in spore and stalk cells of $D$. mucoroides, $D$. rosarium, $D$. purpureum, $P$. violaceum and $P$. pallidum were analysed by SDS-PAGE. As shown in Fig. 1, many cell-type specific proteins were observed both in spore and stalk cells of each species examined. In the case of $\boldsymbol{P}$. pallidum, the relative amount of WGAbinding proteins is distinctly smaller than that of the other strains examined. However, if a larger amount of total protein is subjected to electrophoresis, a considerable number of cell-type specific WGA-binding proteins can be identified in $P$. pallidum (data not shown). Analysis of the total protein of spore and stalk cells of each species by biotin blotting revealed small differences between the two cell-types which were very difficult to identify reproducibly in 1-D gels (data not shown).

Among the cell-type specific proteins in Fig. 1, we directed our attention to the 34-36 kDa WGA-binding proteins present in stalk cells of $D$. mucoroides $(\mathrm{Dm}$-st 34$)$, $D$. rosarium (Dr-st36) and $P$. violaceum $(\mathrm{Pv}$-st36) because these proteins appeared to be similar to wst34 which had been identified in stalk cells of $D$. discoideum (Kubohara \& Okamoto, 1990). To examine whether these proteins were homologous to wst34, we carried out immunoblots using two antisera. One antiserum was raised against purified wst34 (anti-wst34); the other was raised against D. mucoroides stalk (anti-Dmst) and had been found to recognize wst34 (Kubohara \& Okamoto, 1990). As shown in Fig. 2(a), anti-wst34 recognized a $34 \mathrm{kDa}$ band

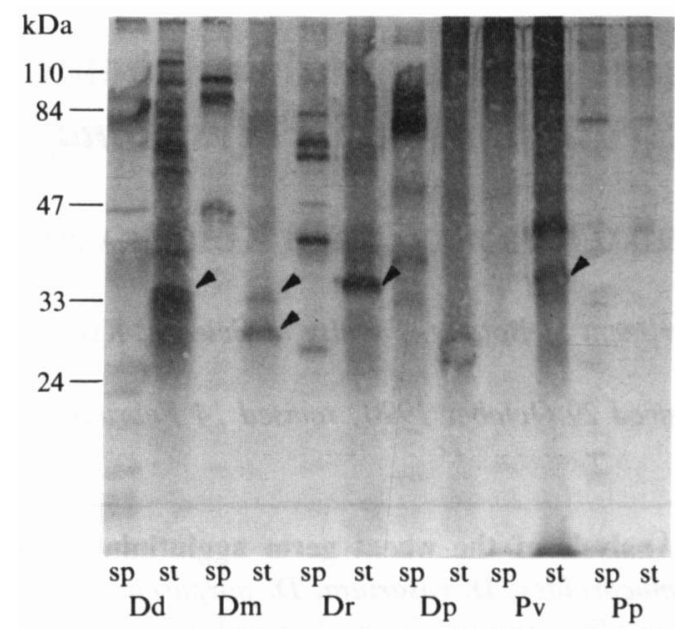

Fig. 1. WGA-binding proteins of the cellular slime moulds. Spore (sp) and stalk (st) proteins of $D$. discoideum (Dd), D. mucoroides $(\mathrm{Dm}), D$. rosarium $(\mathrm{Dr}), D$. purpureum $(\mathrm{Dp}), P$. violaceum $(\mathrm{Pv})$ and $P$. pallidum (Pp) were analysed by SDS-PAGE. Blotted proteins $(20 \mu \mathrm{g}$ per lane) were detected by the WGA-PAP method. Arrowheads indicate (from left to right) wst34, Dm-st34, Dm-st28, Dr-st36 and Pv-st36.

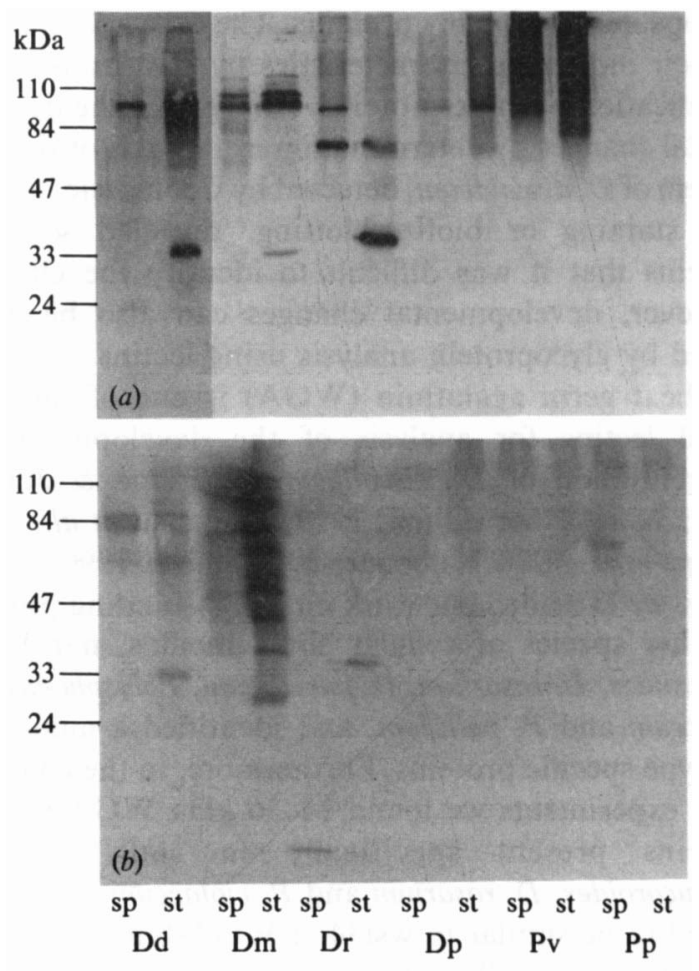

Fig. 2. Immunoblot analysis. Spore (sp) and stalk (st) proteins of the cellular slime moulds were analysed by SDS-PAGE. Blotted proteins $(20 \mu \mathrm{g}$ per lane) were detected with $(a)$ anti-wst 34 or $(b)$ anti-Dmst. Abbreviations are defined in legend to Fig. 1. 

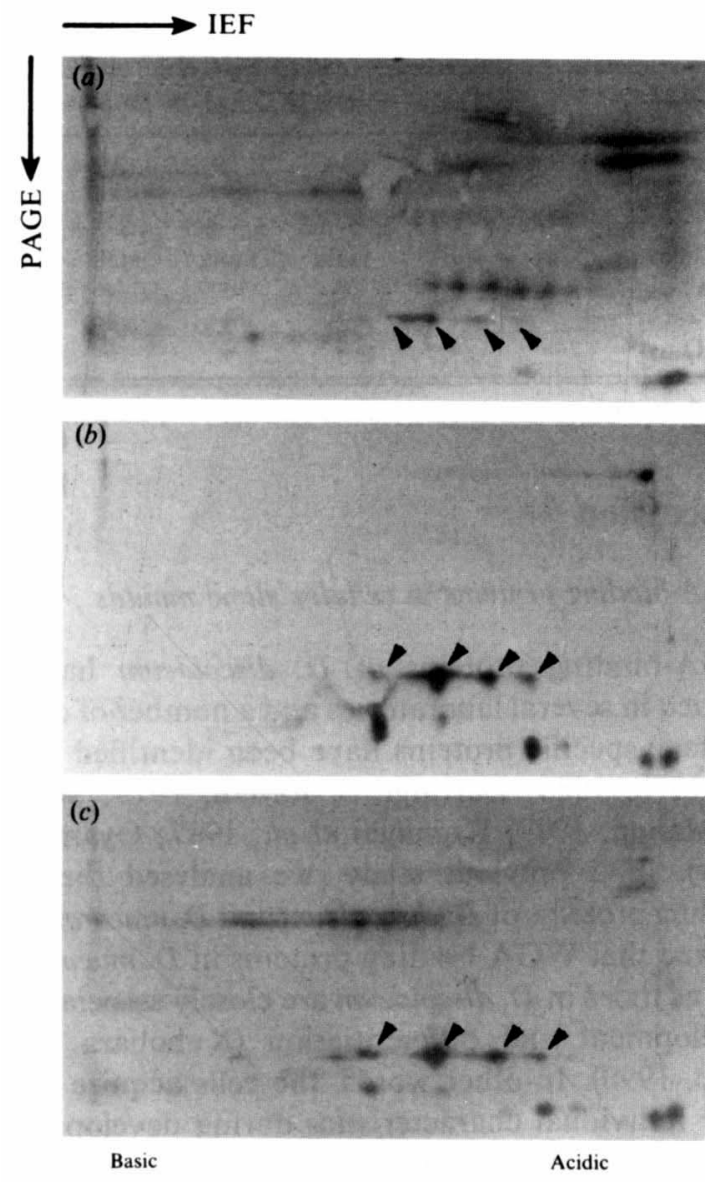

Fig. 3. 2-D gel analysis of wst-34. Stalk proteins (approx. $50 \mu \mathrm{g}$ ) of $D$. discoideum were analysed by 2-D gel electrophoresis. Blotted proteins were detected by the use of $(a)$ WGA, $(b)$ anti-wst34 serum or $(c)$ antiDmst serum. Arrowheads indicate the components of wst 34 .
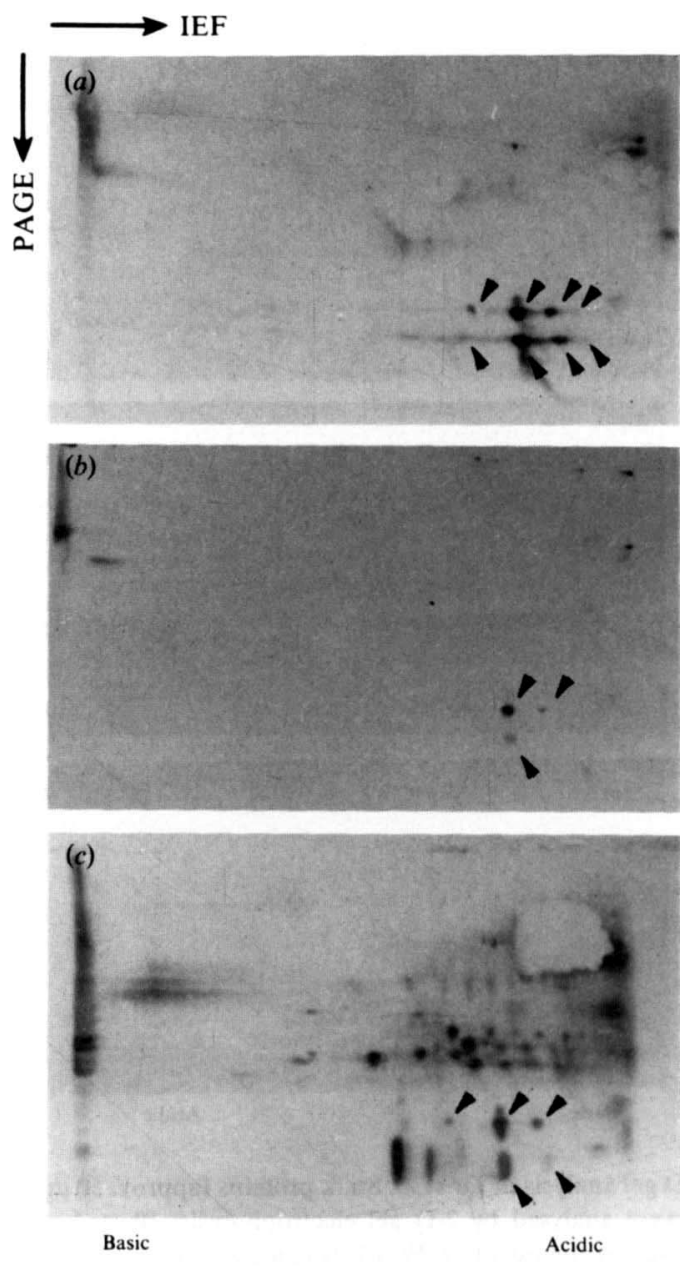

Fig. 4. 2-D gel analysis of Dm-st34 and Dm-st28. Stalk proteins (approx. $50 \mu \mathrm{g}$ ) of $D$. mucoroides were analysed by $2-\mathrm{D}$ gel electrophoresis. Blotted proteins were detected by the use of $(a)$ WGA, $(b)$ antiwst34 serum or $(c)$ anti-Dmst serum. Arrowheads indicate the components of Dm-st34 and Dm-st28.

blots, whether the two antisera really recognize wst 34 , Dm-st34 and Dr-st36. Wst34 and Dm-st34 have pI values of 5.5-6.5 and consist of four components in 2-D gels (Figs 3 and 4). In contrast, Dr-st36 has pI values of 4.85.8 and consists of at least four components in 2-D gels (Fig. 5), while Pv-st36 has pI values of 4.8-5.8 with three or four components similar to those of Dr-st36 (Fig. 6). It should be noted that Dm-st28 produces four spots in 2-D gels with almost the same pattern as Dm-st34, and is recognized by anti-wst34 (Fig. 4). From the analysis of 2-D gels, we concluded that the two antisera recognize wst34, Dm-st34, and Dr-st36 that are defined with WGA. Table 1 summarizes the characteristics of these wst34-like proteins. 

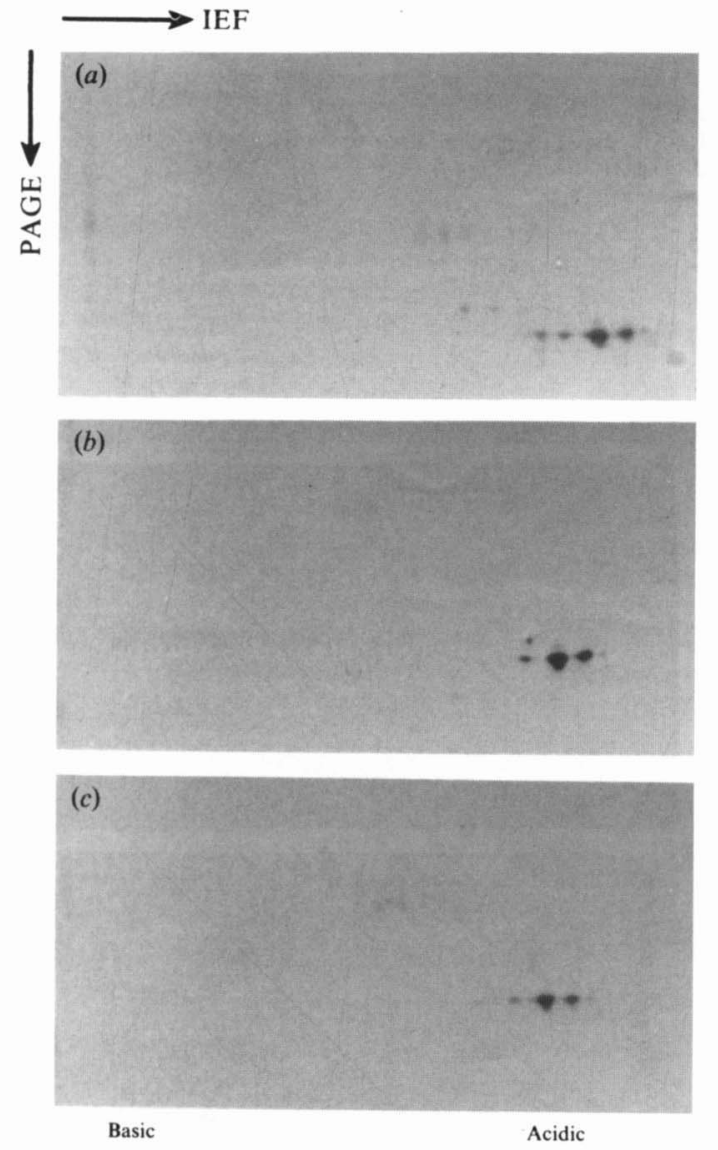

Fig. 5. 2-D gel analysis of Dr-st36. Stalk proteins (approx. $50 \mu \mathrm{g}$ ) of $D$. rosarium were analysed by 2-D gel electrophoresis. Blotted proteins were detected by the use of $(a)$ WGA, $(b)$ anti-wst34 serum or $(c)$ antiDmst serum

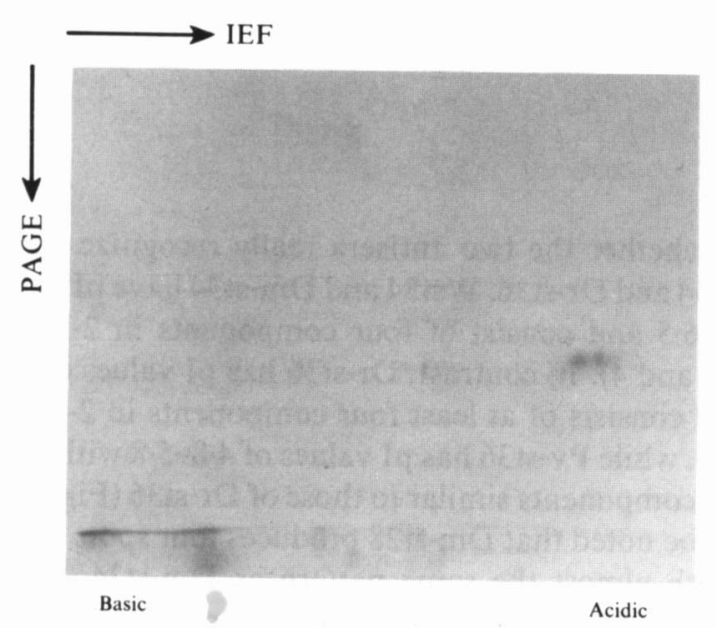

Fig. 6. 2-D gel analysis of Pv-st36. Stalk proteins (approx. $50 \mu \mathrm{g}$ ) of $P$. violaceum were analysed by $2-\mathrm{D}$ gel electrophoresis. Blotted proteins were detected by the use of WGA. Note that Pv-st36 produced at least four spots in another gel (data not shown).
Table 1. Comparison of wst34-like proteins

\begin{tabular}{lccccc}
\hline \hline & wst34 & Dm-st34 & Dm-st-28 & Dr-st36 & Pv-st36 \\
\hline $\begin{array}{l}\text { Molecular mass } \\
\text { (kDa) }\end{array}$ & 34 & 34 & 28 & 36 & 36 \\
pI value & $5 \cdot 5-6 \cdot 5$ & $5 \cdot 5-6 \cdot 5$ & $5 \cdot 5-6 \cdot 5$ & $4 \cdot 8-5 \cdot 8$ & $4 \cdot 8-5 \cdot 8$ \\
Cell-type specificity & stalk & stalk & stalk & stalk & stalk \\
WGA* & + & + & + & + & + \\
Anti-wst34* & + & \pm & \pm & + & - \\
Anti-Dmst* & + & + & + & + & - \\
\hline \hline
\end{tabular}

$*+$, Strong reaction; \pm , weak reaction; - , no reaction.

\section{Discussion}

WGA-binding proteins in cellular slime moulds

WGA-binding proteins of $D$. discoideum have been studied in several laboratories and a number of cell-typeor stage-specific proteins have been identified (West et al., 1978, 1986; Burridge \& Jordan, 1979; West and McMahon, 1979; Kumagai et al., 1987; Oyama et al., 1988). In a previous study, we analysed the WGAbinding proteins of $D$. discoideum and $D$. mucoroides, and showed that WGA-binding proteins in D. mucoroides as well as those in $D$. discoideum are closely associated with development and differentiation (Kubohara \& Okamoto, 1990). In other words, the cells acquire some of their individual characteristics during development by post-translational modification of proteins that can be recognized with WGA. In the present study, we examined WGA-binding proteins of other species of cellular slime moulds and found many differences between spore and stalk cells of all species examined (Fig. 1). Because cell-type-specific proteins are not easy to characterize in bulk-protein analysis by 1-D gels, WGA may be a useful tool for analysing the development and differentiation of cellular slime moulds.

Yamada et al. (1988) compared spore proteins among several species of cellular slime moulds, and demonstrated that $P$. violaceum is closely related to $D$. discoideum and $D$. mucoroides as far as spore proteins are concerned. Our present results show that $P$. violaceum has, like Dictyostelium spp., many cell-type-specific WGA-binding proteins, while in $P$. pallidum, the amount of WGA-binding proteins is very low (Fig. 1). Taken together, these results suggest that $P$. violaceum might be more closely related to the Dictyostelium genus than $P$. pallidum.

\section{Wst34-like proteins}

The present findings show that wst34-like proteins are likely to be present in stalk cells of $D$. discoideum (wst34), D. mucoroides (Dm-st34), D. rosarium (Dr-st36) and $P$. 
violaceum $(\mathrm{Pv}$-st36). Some of the properties of wst34 and Dm-st34 have been reported previously (Kubohara \& Okamoto, 1990). Wst34 in D. discoideum is a stalkspecific WGA-binding protein, which has a molecular mass of $34 \mathrm{kDa}$ and $\mathrm{pI}$ values of between 5.5 and 6.5. In normal development, wst 34 appears during the culmination stage and is maintained in stalk cells of fruiting bodies. Wst 34 is thought to be localized in the cytoskeleton or extracellular matrix of the stalk cells because this protein is not solubilized with a $1 \%(\mathrm{w} / \mathrm{v})$ Triton X-100 solution. In the present study, we verified the identity of the wst34-like proteins in the four species by 2-D gel analysis and by immunoblots using two antisera that recognize wst 34 . WGA-binding ability and cell-type specificity are the common properties of the four proteins, but as far as molecular mass and $\mathrm{pI}$ values are concerned, there seem to be two groups - one for wst34 and Dm-st34, the other for Dr-st36 and Pv-st36 (Table 1). The fact that wst 34 consists of four components and not three as previously found (Kubohara \& Okamoto, 1990), is probably because one component of wst34 was lost during purification.

Dm-st34 is the most probable candidate for a wst34like protein, because all the charactristics of Dm-st 34 are the same as wst34, except for the fact that anti-wst34 recognized only two components of Dm-st34 in 2-D gels (Fig. 4). It is interesting that Dm-st28 produces four spots in 2-D gels with pI values of 5.5-6.5 and is partially recognized by anti-wst34 (Fig. 4). This implies that there might be some relationship between Dm-st34 and Dmst28 in vivo.

As for Dr-st36, since it is strongly recognized by the two antisera and appears at the late stage in normal development (data not shown), it should be regarded as a wst34-like protein. Although Dr-st36 differs from wst34 in molecular mass and $\mathrm{pI}$ values, this can be explained by assuming that Dr-st36 is modified with many more carbohydrates carrying negatively charged groups, such as sulphates.

$\mathrm{Pv}$-st36 differs from wst 34 in molecular mass and $\mathrm{pI}$ values, and it is not recognized by the antisera anti-wst 34 and anti-Dmst. However, since Pv-st 36 is very similar to Dr-st36 in some respects (Table 1), we still regard it as a candidate for a wst34-like protein.

If wst34-like proteins are conserved in these species, the proteins may play an important role in the formation of the stalk, functionally or structurally. To confirm the identity of these proteins, further study will be necessary, including the analysis of their function(s).

We thank Dr Kei Inouye and Dr Bert Van Duijn for their critical reading of the manuscript. We also thank Kunito Yoshida, Miwa Hashimoto, and Satoru Miyayama, by whom a part of this work was undertaken in a course programme for undergraduate students.

\section{References}

BURRIDGE, K. \& JORDAN, L. (1979). The glycoproteins of Dictyostelium discoideum. Experimental Cell Research 124, 31-38.

IsHIDA, S. (1980). A mutant of Dictyostelium discoideum capable of differentiating without morphogenesis. Development Growth and Differentiation 22, 143-152.

Kubohara, Y. \& OKamoto, K. (1990). A stalk-specific wheat germ agglutinin binding protein, wst 34 , in Dictyostelium discoideum can be detected with antiserum raised against Dictyostelium mucoroides stalk. Biochemistry and Cell Biology 68, 699-704.

Kumagai, A., Mori, H., OsuKa, S. \& OKamoto, K. (1987). Prespore and prestalk differentiation of Dictyostelium discoideum as examined by changes of wheat germ agglutinin binding proteins. Biochemistry and Cell Biology 65, 68-75.

LAEMMLI, U. K. (1970). Cleavage of structural proteins during the assembly of the head of bacteriophage T4. Nature, London 227, 680 .

O'FarRell, P. H. (1975). High resolution two-dimensional electrophoresis of proteins. Journal of Biological Chemistry 250, 4007-4021.

Oyama, M., Kubohara, Y., Oohata, A. A. \& Okamoto, K. (1988). Role of cyclic AMP and ammonia in induction and maintenance of post-aggregative differentiation in a suspension culture of Dictyostelium discoideum. Differentiation 38, 11-16.

Smith, P. K., Krohn, R. I., Hermanson, G. T., Mallia, A. K., Gartner, F. H., Provenzano, M. D., Fujimoto, E. K., Goeke, N. M., OLSON, B. J. \& KLENK, D. C. (1985). Measurement of protein using bicinchoninic acid. Analytical Biochemistry 150, 76-85.

Sussman, M. (1951). The origin of cellular heterogeneity on the slime molds, Dictyosteliaceae. Journal of Experimental Zoology 118 , 407-418.

Towbin, H., Staehelin, T. \& Gordon, J. (1979). Electrophoretic transfer of proteins from polyacrylamide gels to nitrocellulose sheets: procedure and some applications. Proceedings of the National Academy of Sciences of the United States of America 76, 4350-4354.

WEST, C. M. \& MCMAHON, D. (1979). The axial distribution of plasma membrane molecules in pseudoplasmodia of the cellular slime mold Dictyostelium discoideum. Experimental Cell Research 124, 393-401.

WEST, C. M., MCMAHON, D. \& MOLDAY, R. S. (1978). Identification of glycoproteins, using lectins as probes, in plasma membranes from Dictyostelium discoideum and human erythrocytes. Journal of Biological Chemistry 253, 1716-1724.

West, C. M., ERdos, G. W. \& Davis, R. (1986). Glycoantigen expression is regulated both temporally and spatially during development in the cellular slime molds Dictyostelium discoideum and D. mucoroides. Molecular and Cellular Biochemistry 72, 121-140.

Yamada, Y., OKamoto, K. \& TakeUchi, I. (1988). Comparison of spore proteins among species of the cellular slime moulds Dictyostelium and Polysphondylium. Canadian Journal of Microbiology 34, 891-896. 